\title{
Double somatic mosaicism in a child with Dravet syndrome
}

Alison M. Muir, PhD, Chontelle King, BSc, Amy L. Schneider, MGC, Aman S. Buttar, BSC, Ingrid E. Scheffer, MB, BS, PhD, Lynette G. Sadleir, MB, ChB, MD, and Heather C. Mefford, MD, PhD

Neurol Genet 2019;5:e333. doi:10.1212/NXG.0000000000000333

Dravet syndrome, the prototypic infantile-onset developmental and epileptic encephalopathy, occurs secondary to de novo pathogenic variants in SCN1A in over $80 \%$ of cases ${ }^{1}$. One possible genetic etiology for patients without a heterozygous $S C N 1 A$ mutation is a post-zygotic mosaic $S C N 1 A$ variant below the level detected by diagnostic sequencing, which routinely identifies only variants with allele frequencies above $\sim 20 \%$. We used targeted deep resequencing to systematically investigate whether mosaicism could be the cause in individuals with molecularly unsolved Dravet syndrome.

\section{Results}

Using single-molecule molecular inversion probes, ${ }^{2}$ we performed deep sequencing of SCN1A and 7 other Dravet-associated genes (SCN2A, SCN8A, HCN1, GABRA1, GABRG2, STXBP1, and $P C D H 19)$ using DNA derived from blood or saliva of 20 individuals with a clinical diagnosis of Dravet or Dravet-like syndrome. Previous targeted sequencing had not identified a heterozygous pathogenic variant in SCN1A or 65 other epilepsy genes.

We identified an individual who was mosaic for 2 different pathogenic variants at the same nucleotide position in SCN1A: chr2:g.166848363A > G, p.(Phe1808Leu) and chr2: g.166848363A > C, p. (Phe1808Val). The SCN1A variants were present in the blood at allele frequencies of $8.3 \%$ and $6.9 \%$, respectively, which is well below the level of detection by standard targeted and Sanger sequencing technologies. We were able to detect both variants at varying allele frequencies (ranging from $0.6 \%$ to $39.7 \%$ ) in DNA derived from hair follicles and skin fibroblasts (figure, A and B). Through cloning and sequencing a fragment containing both a maternally inherited SNP (rs10497275) and the mosaic variant site, we determined that both variants are located on the paternal allele.

This 12-year-old girl presented at 6 months with a brief febrile generalized tonic-clonic seizure (GTCS). She continued to have occasional febrile GTCS until 1 year of age when she had 3 10minute focal motor seizures; 1 left hemiclonic and 1 followed by a postictal right Todd's paresis. At 2 years, she developed clusters (up to 15 seizures over 4 days) of focal impaired awareness facial clonic seizures every 6 weeks. Her first episode of status epilepticus occurred at 3 years. Development was normal until 2 years when language delay became apparent and attention deficit hyperactivity disorder and autism spectrum disorder were diagnosed. Despite trials of valproate, carbamazepine, lamotrigine, topiramate, clobazam, and cannabidiol, her seizures remain intractable. EEGs at 17 months and 3 years showed no epileptiform discharges. Subsequent EEGs have not been possible due to behavior. MRI and routine metabolic and CSF studies are normal.

\author{
Correspondence \\ Dr. Mefford \\ hmefford@uw.edu
}




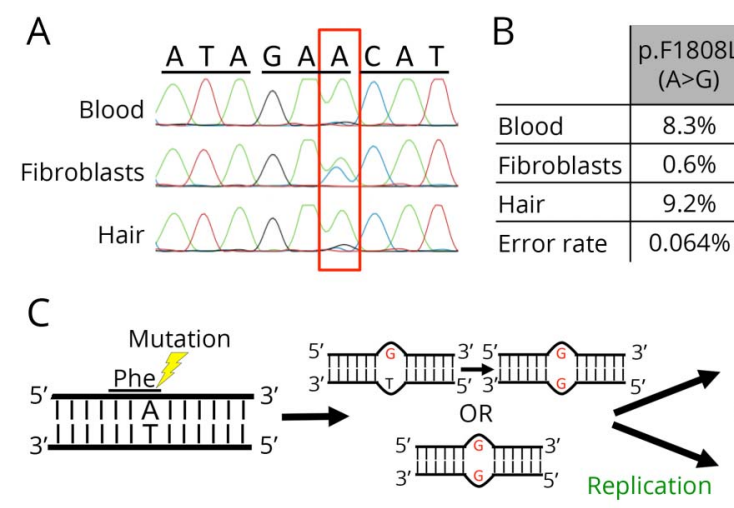

\section{Discussion}

Double somatic mosaicism, where 2 mosaic variants occur at the same nucleotide, has not been reported in Dravet syndrome and only rarely recognized in human diseases ${ }^{3,4}$; recently, a single case was reported in SCN2A encephalopathy. ${ }^{4}$ We detected double mosaicism in SCN1A in a patient with Dravet syndrome. The variants are predicted to cause different amino acid changes at the same residue (p.Phe1808). Both variants are present in cells derived from ectodermal (hair follicles) and mesodermal (leukocytes and skin fibroblasts) tissues. That neither variant is limited to a single germ layer strongly suggests that the mutations occurred prior to gastrulation. Although brain tissue is unavailable for confirmation, these findings suggest that both variants should be present in brain, another ectodermal tissue.

It is estimated that every individual accumulates approximately 8 spontaneous mutations per somatic cell division. ${ }^{5}$ Since both mutations occurred after the first cell cleavage but before gastrulation, it is improbable that spontaneous mutations randomly occurred at the same nucleotide twice in such a narrow developmental window. It is also unlikely that this non-cytosine-phosphate-guanine nucleotide has an appreciably higher mutation rate than the genome average. The excess of triallelic sites present in the genome supports the occurrence of simultaneous mutations on opposite strands of the same DNA molecule. ${ }^{6}$ This model would explain the double mosaicism of the same nucleotide in our patient and is supported by the finding that both mosaic variants occurred on the paternal allele (figure, C).

Based on American College of Medical Genetics and Genomics guidelines, ${ }^{7}$ both SCN1A:p.(Phe1808Leu) and SCN1A: p.(Phe1808Val) are classified as pathogenic variants. Therefore, approximately $15.2 \%$ of SCN1A alleles harbor pathogenic mutations in the blood of our patient. We recently reported 2 parents with febrile seizures who were mosaic for SCN1A variants with $17.6 \%$ and $30.6 \%$ mosaic allele frequencies in blood respectively, while their nonmosaic offspring had Dravet syndrome. ${ }^{2}$ In contrast to the milder phenotypes in the parents with mosaic variants in these families, our patient reported here had the classical features of Dravet syndrome similar to a reported individual who was heterozygous for the same p.(Phe1808Leu) pathogenic variant. ${ }^{8}$ Marked differences in phenotypic severity associated with mosaicism are likely explained by variation in mosaicism levels in disease-relevant tissues. For the brain, perhaps this may even be determined by region-specific and cell-type-specific differences. Comprehensive studies of disease-relevant tissue will be required to gain a more accurate picture of somatic mosaicism levels and how this affects disease severity.

\section{Study funding}

Supported by grants from the NINDS (R01 NS069605, to Dr. Mefford).

\section{Disclosure}

Disclosures available: Neurology.org/NG.

\section{Publication history}

Received by Neurology: Genetics January 23, 2019. Accepted in final form March 18, 2019.

Appendix Authors

\begin{tabular}{llll}
\hline Name & Location & Role & Contribution \\
\hline $\begin{array}{l}\text { Alison } \\
\text { Muir, PhD }\end{array}$ & $\begin{array}{l}\text { University of } \\
\text { Washington, } \\
\text { Seattle }\end{array}$ & Author & $\begin{array}{l}\text { Contributed to conception } \\
\text { and design of the study, } \\
\text { acquisition and analysis of } \\
\text { sequencing data, and } \\
\text { drafting and revision of the } \\
\text { manuscript }\end{array}$ \\
\hline $\begin{array}{l}\text { Chontelle } \\
\text { King, BSc }\end{array}$ & $\begin{array}{l}\text { University of } \\
\text { Otago, } \\
\text { Wellington }\end{array}$ & Author & $\begin{array}{l}\text { Contributed to acquisition } \\
\text { and analysis of data of } \\
\text { clinical data for the case } \\
\text { report }\end{array}$ \\
\hline
\end{tabular}


Appendix (continued)

\begin{tabular}{|c|c|c|c|}
\hline Name & Location & Role & Contribution \\
\hline $\begin{array}{l}\text { Amy } \\
\text { Schneider, } \\
\text { MGC }\end{array}$ & $\begin{array}{l}\text { The University } \\
\text { of Melbourne, } \\
\text { Heidelberg }\end{array}$ & Author & $\begin{array}{l}\text { Contributed to acquisition } \\
\text { and analysis of data clinical } \\
\text { data for the Dravet cohort }\end{array}$ \\
\hline $\begin{array}{l}\text { Aman S. } \\
\text { Buttar, BSc }\end{array}$ & $\begin{array}{l}\text { University of } \\
\text { Washington, } \\
\text { Seattle }\end{array}$ & Author & $\begin{array}{l}\text { Determined the allele of } \\
\text { origin for the mosaic } \\
\text { mutations }\end{array}$ \\
\hline $\begin{array}{l}\text { Ingrid } \\
\text { Scheffer, } \\
\text { MB, BS, } \\
\text { PhD }\end{array}$ & $\begin{array}{l}\text { The University } \\
\text { of Melbourne, } \\
\text { Heidelberg }\end{array}$ & Author & $\begin{array}{l}\text { Contributed to acquisition and } \\
\text { analysis of clinical data for the } \\
\text { Dravet cohort, and drafting } \\
\text { and revision of the manuscript }\end{array}$ \\
\hline $\begin{array}{l}\text { Lynette } \\
\text { Sadleir, } \\
\text { MB, ChB, } \\
\text { MD }\end{array}$ & $\begin{array}{l}\text { University of } \\
\text { Otago, } \\
\text { Wellington }\end{array}$ & Author & $\begin{array}{l}\text { Contributed to acquisition and } \\
\text { analysis of clinical data for the } \\
\text { case report, and drafting and } \\
\text { revision of the manuscript }\end{array}$ \\
\hline $\begin{array}{l}\text { Heather } \\
\text { Mefford, } \\
\text { MD, PhD }\end{array}$ & $\begin{array}{l}\text { University of } \\
\text { Washington, } \\
\text { Seattle }\end{array}$ & Author & $\begin{array}{l}\text { Contributed to conception } \\
\text { and design of the study, and } \\
\text { drafting and revision of the } \\
\text { manuscript }\end{array}$ \\
\hline
\end{tabular}

\section{References}

1. Claes L, Del-Favero J, Ceulemans B, Lagae L, Van Broeckhoven C, De Jonghe P, et al. De novo mutations in the sodium-channel gene SCN1A cause severe myoclonic epilepsy of infancy. Am J Hum Genet 2001;68:1327-1332.

2. Myers CT, Hollingsworth G, Muir AM, et al. Parental mosaicism in "de novo" epileptic encephalopathies. N Engl J Med 2018;378:1646-1648.

3. Draaken M, Giesen CA, Kesselheim AL, et al. Maternal de novo triple mosaicism for two single OCRL nucleotide substitutions (c.1736A $>\mathrm{T}, \mathrm{c} .1736 \mathrm{~A}>\mathrm{G})$ in a Lowe syndrome family. Hum Genet 2011;129:513-519.

4. Stosser MB, Lindy AS, Butler E, et al. High frequency of mosaic pathogenic variants in genes causing epilepsy-related neurodevelopmental disorders. Genet Med 2018;20: 403-410.

5. Milholland B, Dong X, Zhang L, Hao X, Suh Y, Vijg J, Differences between germline and somatic mutation rates in humans and mice. Nat Commun 2017;8: 15183.

6. Hodgkinson A, Eyre-Walker A. Human triallelic sites: evidence for a new mutational mechanism? Genetics 2010;184:233-241.

7. Richards S, Aziz N, Bale S, et al. Standards and guidelines for the interpretation of sequence variants: a joint consensus recommendation of the American College of Medical Genetics and Genomics and the Association for Molecular Pathology. Genet Med 2015; 17:405-424.

8. Fujiwara T, Sugawara T, Mazaki-Miyazaki E, et al. Mutations of sodium channel alpha subunit type 1 (SCN1A) in intractable childhood epilepsies with frequent generalized tonic-clonic seizures. Brain 2003;126(pt 3):531-546. 


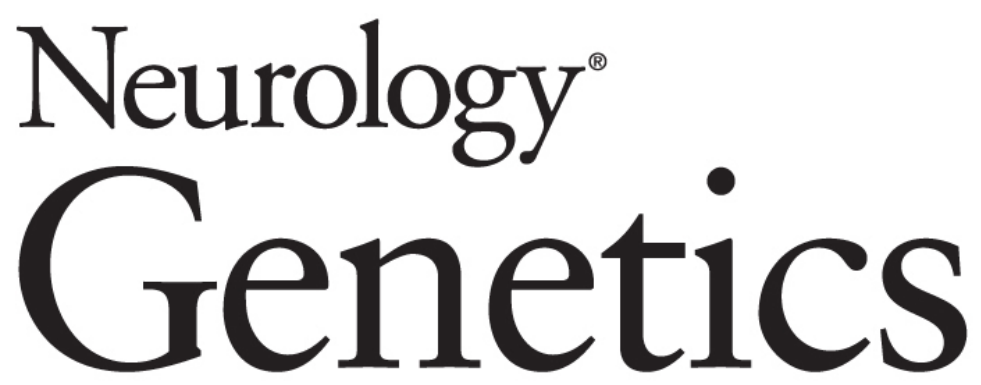

Double somatic mosaicism in a child with Dravet syndrome Alison M. Muir, Chontelle King, Amy L. Schneider, et al. Neurol Genet 2019;5;

DOI 10.1212/NXG.0000000000000333

This information is current as of April 19, 2019

Neurol Genet is an official journal of the American Academy of Neurology. Published since April 2015, it is an open-access, online-only, continuous publication journal. Copyright Copyright () 2019 The Author(s). Published by Wolters Kluwer Health, Inc. on behalf of the American Academy of Neurology.. All rights reserved. Online ISSN: 2376-7839.

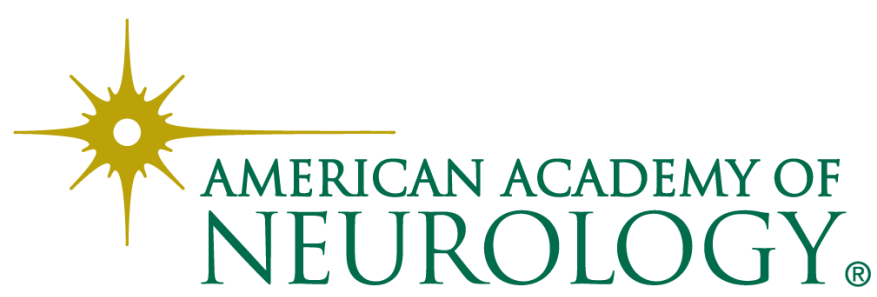




\section{Updated Information \& Services}

References

Subspecialty Collections

Permissions \& Licensing

\section{Reprints}

including high resolution figures, can be found at:

http://ng.neurology.org/content/5/3/e333.full.html

This article cites 8 articles, 1 of which you can access for free at: http://ng.neurology.org/content/5/3/e333.full.html\#\#ref-list-1

This article, along with others on similar topics, appears in the following collection(s):

All Epilepsy/Seizures

http://ng.neurology.org//cgi/collection/all_epilepsy_seizures

\section{All Genetics}

http://ng.neurology.org//cgi/collection/all_genetics

Cohort studies

http://ng.neurology.org//cgi/collection/cohort_studies

Developmental disorders

http://ng.neurology.org//cgi/collection/developmental_disorders

Ion channel gene defects

http://ng.neurology.org//cgi/collection/ion_channel_gene_defects

Information about reproducing this article in parts (figures,tables) or in its entirety can be found online at:

http://ng.neurology.org/misc/about.xhtml\#permissions

Information about ordering reprints can be found online:

http://ng.neurology.org/misc/addir.xhtml\#reprintsus

Neurol Genet is an official journal of the American Academy of Neurology. Published since April 2015, it is an open-access, online-only, continuous publication journal. Copyright Copyright ( 2019 The Author(s). Published by Wolters Kluwer Health, Inc. on behalf of the American Academy of Neurology.. All rights reserved. Online ISSN: 2376-7839.

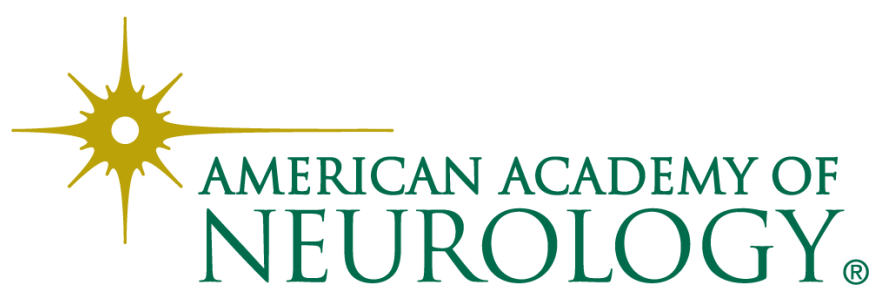

